\title{
The regulatory effect of tamoxifen on fibronectin expression in estrogen-dependent MCF-7 breast carcinoma cells
}

\author{
YOSHIO HORII ${ }^{1}$, HIROYUKI TAKEI ${ }^{1}$, YUKIO KOIBUCHI $^{1}$, JUN HORIGUCHI $^{1}$, \\ MICHIO MAEMURA ${ }^{1}$, YUICHI IINO ${ }^{2}$ and YASUO MORISHITA ${ }^{1}$ \\ Departments of ${ }^{1}$ Thoracic and Visceral Organ Surgery and ${ }^{2}$ Emergency Medicine, Gunma University \\ Graduate School of Medicine, 3-39-22, Showa-machi, Maebashi, Gunma 371-8511, Japan \\ Received November 14, 2005; Accepted December 28, 2005
}

\begin{abstract}
We investigated the regulatory effect of tamoxifen (TAM) on fibronectin (FN) expression in estrogen-dependent MCF-7 breast carcinoma cells both in vitro and in vivo. In vitro, MCF-7 cells were cultured with 17ß-estradiol $\left(\mathrm{E}_{2}\right)$ and/or TAM. In the animal experiment in vivo, MCF-7 tumors were grown in ovariectomized athymic mice by implanting a sustained release $\mathrm{E}_{2}$ pellet. The $\mathrm{E}_{2}$ pellets were removed after 3 weeks of $E_{2}$ treatment. Animals were then divided into four groups: 1) an $\mathrm{E}_{2}(0.72 \mathrm{mg} /$ pellet $)$ pellet $\left.\left[\mathrm{E}_{2}(+)\right] ; 2\right)$ an $\mathrm{E}_{2}$ and a TAM (5 mg/pellet) pellet $\left[\mathrm{E}_{2}(+) \mathrm{TAM}\right]$; 3) no treatment $\left[\mathrm{E}_{2}(-)\right]$ and 4) a TAM pellet $\left[\mathrm{E}_{2}(-) \mathrm{TAM}\right]$. Following each treatment for 4 weeks, all animals were sacrificed and tumors were removed. Specimens, cells (in vitro) or tumors (in vivo), were homogenized and assayed for $\mathrm{FN}$ by Western blots. In the in vitro experiment, FN expression in MCF-7 cells decreased by incubating with $10^{-9} \mathrm{M} \mathrm{E}_{2}$ and increased with $10^{-6} \mathrm{M}$ TAM. The effect of TAM increasing FN expression was inhibited by incubation accompanied with $10^{-9} \mathrm{M} \mathrm{E}_{2}$ or $1 \mu \mathrm{g} / \mathrm{ml}$ transforming growth factor- $\beta$ (TGF- $\beta$ ) neutralizing antibody. In the in vivo animal experiment $\mathrm{FN}$ expression in the tumors of $\mathrm{E}_{2}(+)$ mice was lower than that of $\mathrm{E}_{2}(-)$ mice. However, TAM increased FN expression in the tumors regardless of $\mathrm{E}_{2}$ pellet. These results suggest that TAM increases FN expression of MCF-7 breast carcinoma cells and that these regulatory effects of TAM on FN expression are partly mediated by TAM-induced TGF- 3 .
\end{abstract}

\section{Introduction}

Fibronectine (FN) is a large grycoprotein found ubiquitously in the plasma and other body fluids (plasma FN), in extra-

Correspondence to: Dr Yoshio Horii, Department of Thoracic and Visceral Organ Surgery, Gunma University Graduate School of Medicine, 3-39-22, Showa-machi, Maebashi, Gunma 371-8511, Japan

E-mail: y.horii@jcom.home.ne.jp

Key words: fibronectin, breast cancer, estrogen receptor, tamoxifen, $17 ß$-estradiol, transforming growth factor- $\beta$ cellular matrices, on the surface of cells, and in basement membranes (cellular FN) $(1,2)$. FN plays a key role in the tissue remodeling and cell migration events that occur during normal embryonic development and adult wound healing (3), and it has been thought to have an important role in both tumor invasion and metastasis (4).

FN has been proven to be produced by various cancer cells including breast cancer (5-7). Takei and his co-workers reported that $\mathrm{FN}$, which is deposited in the stroma surrounding breast cancer cells, analyzed by immunohistochemistry was a prognostic indicator of patients with breast cancer. It was also shown that the relapse-free survival of patients with FNpositive tumors was significantly better than patients with FN-negative tumors (8).

Cellular FN is a major constituent of the cell surface of many cultured cells, and it is either eliminated or reduced in presence on the surface of oncogenically transformed cells $(1,2)$. Several studies have suggested that there is a correlation between the loss of cell surface FN and the ability of a cell to metastasize (9-11).

FN expression is regulated by a variety of growth factors and hormones, such as glucocorticoids, transforming growth factor- $\beta$ (TGF- $\beta$ ), cAMP, epidermal growth factor, plateletderived growth factor, vitamin $\mathrm{D}_{3}$, and estrogen $(12,13)$. However, the regulatory mechanism of FN expression of breast carcinoma is not clear. Investigation of the regulatory mechanism is, therefore, expected to lead to the elucidation of suppressive regulation of the metastasis of breast cancer.

Tamoxifen (TAM), a non-steroidal antiestrogen, is a standard treatment medicine for patients with estrogen receptor-positive breast cancer. Five years of TAM has been shown to significantly improve long-term survival of patients with estrogen receptor-positive breast cancer (14). Although the antitumor action of TAM is to competitively block estrogens from binding to the estrogen receptor of breast cancer, the whole process of this antitumor action of TAM remains to be clarified.

TAM reportedly stimulated the production of TGF- $\beta$ in vitro (15) and in vivo (16), and inhibited that of vascular endothelial growth factor (VEGF) in vitro in breast cancer (17). However, few investigations concerning the effect of TAM on FN expression in breast cancer have been reported. Thus, we were interested in whether or not TAM effected FN expression in estrogen-dependent breast carcinoma cells. 


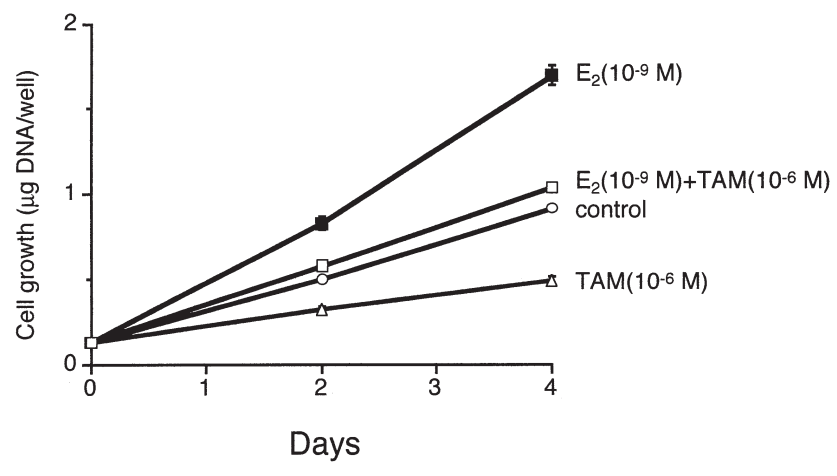

Figure 1. Proliferative effects of 17ß-estradiol $\left(\mathrm{E}_{2}\right)$ and tamoxifen (TAM) on cell growth in MCF-7 cells in vitro. $\mathrm{MCF}-7$ cells were plated to each well of a 96-well culture plate and were incubated with $\mathrm{E}_{2}\left(10^{-9} \mathrm{M}\right)$ and/or TAM $\left(10^{-6} \mathrm{M}\right)$ for 4 days. DNA was measured at the indicated number of days. Each point included hexaplicated data presented as mean \pm SEM. When MCF-7 cells were incubated with $E_{2}$, cell growth was significantly $(p<0.01$ vs. control) stimulated. To the contrary, when the cells were incubated with TAM, cell growth was reduced to $\sim 50 \%$ of the control level ( $p<0.01$ vs. control). Furthermore, when MCF-7 cells were incubated with TAM together with $E_{2}$, stimulating effect of $E_{2}$ on cell growth was approximately inhibited to the control level.

In the present study, we evaluated the regulatory effect of TAM on FN expression in estrogen-dependent MCF-7 breast carcinoma cells in vitro and in vivo.

\section{Materials and methods}

Media and chemicals. $\mathrm{E}_{2}$ and TAM were obtained from Sigma Chemical Company (St. Louis, MO). TGF-ß1 neutralizing antibody was obtained from R\&D Systems (Minneapolis, $\mathrm{MN}) . \mathrm{E}_{2}$ (0.72 mg/pellet, 60-day sustained release) and TAM (5 mg/pellet, 60-day sustained release) pellets were obtained from Innovative Research of America (Sarasota, FL). Immobilon ${ }^{\mathrm{TM}}$ PVDF (polyvinyldene difluoride) transfer membrane for Western blotting was from Millipore Corp. (Bedford, MA). ECL ${ }^{\text {TM }}$ Western blotting detection reagent was from Amersham International Plc. (Buckinghamshire, UK). The antibody to FN was from Oncogene Research Products (Cambridge, MA). The secondary antibody, horseradish-peroxidase-linked sheep anti-mouse IgG was from Amersham International. Bio-Rad protein assay dye reagent was from Nippon Bio-Rad (Tokyo). Other reagents were of the highest grade available.

Cell culture. Human breast carcinoma cell lines MCF-7 were generously provided by Dr Robert Dickson (Georgetown University, Washington, DC). The cells were maintained in RPMI-1640 (Gibco BRL, Grand Island, NY) supplemented with $10 \%$ fetal calf serum (FCS; Gibco BRL) and were grown in a humidified atmosphere of $5 \% \mathrm{CO}_{2}$ and $95 \%$ air at $37^{\circ} \mathrm{C}$.

Tumors in nude mice and treatment groups. Athymic mice $[\mathrm{BALB} / \mathrm{c}(\mathrm{nu} / \mathrm{nu})]$ were provided by the Institute of Experimental Animal Research, Gunma University. Sterilized water and diet (MF, Oriental Yeast Co., Ltd., Tokyo) were given

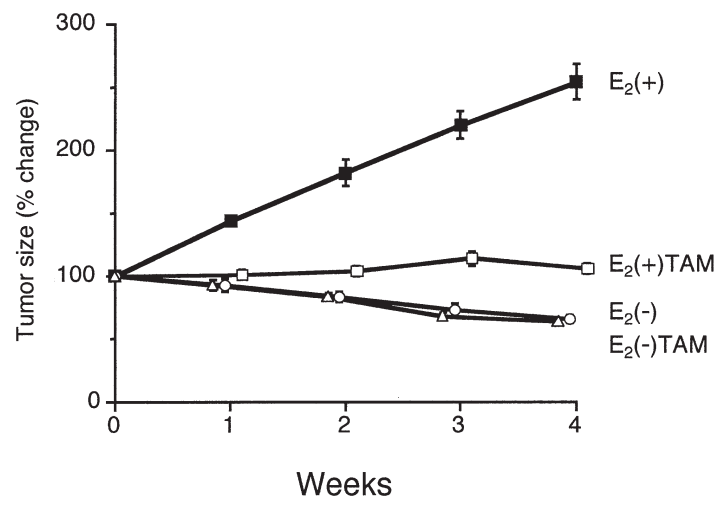

Figure 2. Effects of 17ß-estradiol $\left(\mathrm{E}_{2}\right)$ and tamoxifen (TAM) on tumor growth of MCF-7 tumor implanted in athymic mice. The mice were divited into four groups $\left[\square, \mathrm{E}_{2}(+) ; \square, \mathrm{E}_{2}(+) \mathrm{TAM} ; \circ, \mathrm{E}_{2}(-) ; \triangle, \mathrm{E}_{2}(-) \mathrm{TAM}\right]$ and treated for 4 weeks as described in Materials and methods. Tumor growth continued in the $\mathrm{E}_{2}(+)$ group. The tumor size reduced significantly $(\mathrm{p}<0.01)$ in the $\mathrm{E}_{2}(-)$ group, compared with the $\mathrm{E}_{2}(+)$ group. TAM significantly inhibited MCF-7 tumor growth in the high estrogen enviroment $\left[\mathrm{E}_{2}(+)\right.$ vs. $\left.\mathrm{E}_{2}(+) \mathrm{TAM}, \mathrm{p}<0.01\right]$; however, TAM did not induce further reduction of the tumor size in the low estrogen enviroment $\left[\mathrm{E}_{2}(-)\right.$ vs. $\left.\mathrm{E}_{2}(-) \mathrm{TAM}, \mathrm{NS}\right]$. Each point presented as mean \pm SEM.

ad libitum. Room temperature $\left(24^{\circ} \mathrm{C}\right)$, humidity $(40 \%)$, and $12 \mathrm{~h}$ of light were automatically controlled. A total of $4 \times 10^{6}$ cells of MCF-7 were inoculated bilaterally into the thoracic mammary fat pads (1/side) of 6-week-old athymic mice, which were ovariectomized at 5 weeks old. All animals were also implanted subcutaneously with an $\mathrm{E}_{2}$ pellet because ERpositive MCF-7 tumors fail to grow in the absence of estrogen. After 3 weeks of estrogen treatment, tumors had reached an average size of $0.5 \mathrm{~cm}^{2}$. The $\mathrm{E}_{2}$ pellet was removed from the animals and randomized into groups (6 animals in each group); and then received one of the following treatments: i) an $\mathrm{E}_{2}$ pellet $\left[\mathrm{E}_{2}(+)\right]$; ii) an $\mathrm{E}_{2}$ and a TAM pellet $\left[\mathrm{E}_{2}(+) \mathrm{TAM}\right]$; iii) no treatment $\left[\mathrm{E}_{2}(-)\right]$ and iv) a TAM pellet $\left[\mathrm{E}_{2}(-) \mathrm{TAM}\right]$. Tumor measurements were performed using slide calipers. Tumor sizes were obtained using the formula (length/2 $\mathrm{x}$ width/2) $x \pi$. The size of each tumor was recorded weekly as a percentage of the initial tumor size at day 0 of treatment, and mean values $\pm(\mathrm{SE})$ percentage changes at specific time points were calculated for each group. After 4 weeks, all animals were sacrificed, tumors were removed and cleared of all skin, fat, and obvious necrosis, and snap-frozen in liquid nitrogen. Frozen tumor specimens were stored at $-80^{\circ} \mathrm{C}$ until the experiments.

Cell proliferation assay. Prior to the following assays in vitro, MCF-7 cells were cultured in phenol red-free RPMI-1640 supplemented with $2 \%$ charcoal-stripped FCS for at least 3 days. MCF-7 cells were harvested with $0.1 \%$ trypsin and $0.05 \%$ EDTA in PBS and were plated into 96-well multiplates at $3 \times 10^{3}$ cells/well. A day later, fresh medium both with and without $\mathrm{E}_{2}\left(10^{-9} \mathrm{M}\right)$ and TAM $\left(10^{-6} \mathrm{M}\right)$, respectively, were added. Forty-eight hours later, fresh medium containing test substances was replaced. Cells were cultured for DNA assays. Following the incubation for various number of days, wells containing ethanol-fixed cells 
A

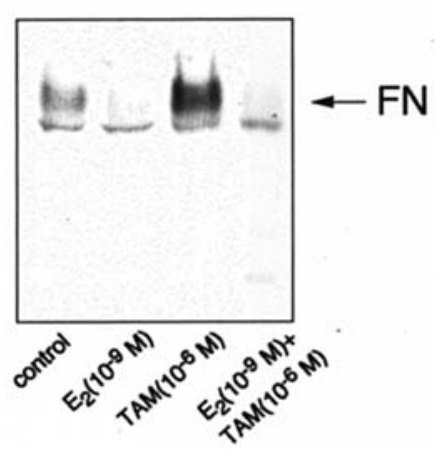

B

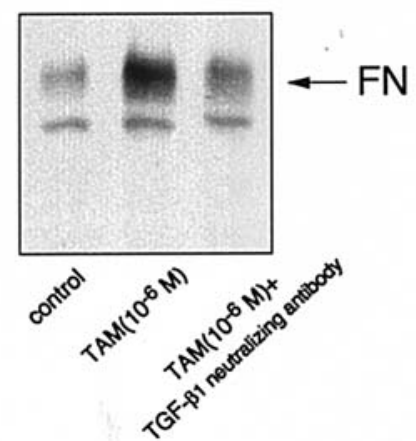

Figure 3. Effects of 17ß-estradiol $\left(\mathrm{E}_{2}\right)$ and tamoxifen (TAM) on cellular fibronectin (FN) expression by Western blots in MCF-7 cells in the in vitro experiment. Sample preparation for grown cells was described in Materials and methods. FN expression in MCF-7 cells decreased by incubating with $10^{-9} \mathrm{M} \mathrm{E}_{2}$ and increased with $10^{-6} \mathrm{M}$ TAM. The effect of TAM increasing FN expression was inhibited by incubating accompanied with $10^{-9} \mathrm{M} \mathrm{E}_{2}$ (A). FN expression upregulated by incubating with TAM decreased by incubating accompanied with $1 \mu \mathrm{g} / \mathrm{ml}$ of TGF- $\beta 1$ neutralizing antibody (B).

were allowed to dry. The DNA content of each well was measured according to Heinegardner (18).

Sample preparation for grown cells in vitro. MCF-7 cells, as described previously, cultured in phenol red-free RPMI-1640 supplemented with $2 \%$ charcoal-stripped FCS for at least 3 days, were harvested with $0.1 \%$ trypsin and $0.05 \%$ EDTA in PBS and were plated into culture dishes. A day later, fresh medium with or without $\mathrm{E}_{2}\left(10^{-9} \mathrm{M}\right)$ and TAM $\left(10^{-6} \mathrm{M}\right)$, respectively, were added. Forty-eight hours later, fresh medium containing test substances was replaced. Cells were cultured for analysis of cell surface FN. Following incubation for 96 h, cells were collected by scraping. The extraction buffer for analysis of $\mathrm{FN}$ contained $10 \mathrm{mM}$ Tris- $\mathrm{HCl}, \mathrm{pH} 7.5 ; 0.25 \mathrm{M}$ sucrose; $5 \mathrm{mM}$ EDTA; $50 \mathrm{mM} \mathrm{NaCl} ; 30 \mathrm{mM}$ sodium pyrophosphate; $50 \mathrm{mM}$ sodium fluoride; $100 \mathrm{mM}$ sodium orthovanadate; $1 \mathrm{mg} / \mathrm{ml}$ pepstatin A; and $2 \mathrm{mg} / \mathrm{ml}$ leupeptin. PMSF (phenylmethylsulfonyl fluoride) $(1 \mathrm{mM})$ was added just before use. Cells were lysed by the extraction buffer mixed with $0.2 \%$ Triton $\mathrm{X}-100$, and homogenized using an ultrasonic cell disruptor Microson XL-2005 (Heat Systems, Farmingdale, $\mathrm{NY}$ ) on ice. All debris and nuclei were removed by centrifugation at $900 \mathrm{x} \mathrm{g}$ for $10 \mathrm{~min}\left(4^{\circ} \mathrm{C}\right)$. All the supernatants were centrifuged at $105,000 \times \mathrm{g}$ for $60 \mathrm{~min}\left(4^{\circ} \mathrm{C}\right)$. The pellet thus obtained was resuspended in the extraction buffer and used as the solubilized membrane fraction for analysis of FN.
Sample preparation for grown tumor in vivo. The specimens were cleared of fat and debris prior to assay. All specimens had a wet weight of 50-100 mg. Samples were homogenized in 4 volumes of the extraction buffer, described above, using a micro-homogenizer NS-310E (Niti-On, Japan) on ice. All debris and nuclei were removed by centrifugation at $900 \mathrm{x}$ $\mathrm{g}$ for $10 \mathrm{~min}\left(4^{\circ} \mathrm{C}\right)$. All the supernatants were centrifuged at $105,000 \mathrm{x} \mathrm{g}$ for $60 \mathrm{~min}\left(4^{\circ} \mathrm{C}\right)$. The pellet thus obtained was resuspended in the extraction buffer, mixed with $0.2 \%$ Triton $\mathrm{X}-100$ and used as the solubilized membrane fraction for analysis of FN.

Western blot analysis. Western blotting was performed according to the modified Laemmli method described in detail previously $(19,20)$. Proteins $(50 \mu \mathrm{g}$ for $\mathrm{FN})$ were separated with sodium dodecyl sulfate (SDS)-polyacrylamide gel electrophoresis (PAGE) using 5\% (w/v) running gel containing acrylamide and N,N'-methylene-bis-acrylamide in the ratio of $37: 1$ in the presence of $0.1 \%(\mathrm{w} / \mathrm{v}) \mathrm{SDS}$, and then transferred to Immobilion ${ }^{\mathrm{TM}}$ PVDF membranes. The PVDF membranes were incubated with $5 \%$ skim milk in Tris-buffered saline (TBS). After washing 3 times in $0.05 \%$ Tween-20-TBS (TBST), the membrane was incubated with $1 \mathrm{mg} / 3 \mathrm{ml}$ antibody to $\mathrm{FN}$ in the TBST for $2 \mathrm{~h}$ at room temperature. After rinsing 3 times in TBST, a secondary antibody solution consisting of $1 \mathrm{mg} / 3 \mathrm{ml}$ horseradishperoxidase-linked sheep anti-mouse Ig and TBST was added, and incubated for $1 \mathrm{~h}$ at room temperature. Proteins were detected with the ECL ${ }^{\mathrm{TM}}$ Western blot detection reagent.

Protein assays. Protein concentrations were determined with bovine serum albumin as the reference standard using the BioRad protein assay dye reagent (21).

Statistical analysis. Values are expressed as the mean \pm the standard error of the mean (SEM). A statistical difference was analyzed between two groups using the Student's t-test or among more than three groups using the Fisher's and the Scheffe's test with an analysis of variance (ANOVA). StatView (SAS Institute, Cary, NC) was used for all statistical analyses and p-values of $<0.05$ were considered to be significant.

\section{Results}

Effects of $E_{2}$ and TAM on cell growth in MCF-7 cells. Fig. 1 shows the effects of $\mathrm{E}_{2}$ and TAM on cell growth in MCF-7 cells in vitro. When MCF-7 cells were incubated with $\mathrm{E}_{2}$ at a concentration of $10^{-9} \mathrm{M}$ for 4 days, cell growth was significantly ( $p<0.01$ vs. control) stimulated. By contrast, after the cells were incubated with TAM at a concentration of $10^{-6} \mathrm{M}$ for 4 days, cell growth was reduced to $\sim 50 \%$ of the control level ( $\mathrm{p}<0.01$ vs. control). Furthermore, when MCF-7 cells were incubated with TAM $\left(10^{-6} \mathrm{M}\right)$ together with $\mathrm{E}_{2}$ $\left(10^{-9} \mathrm{M}\right)$, the stimulating effect of $\mathrm{E}_{2}$ on cell growth was inhibited to the approximate control level.

Growth of MCF-7 tumors in vivo. Prior to the randomization, $\mathrm{E}_{2}$-stimulated tumor growth was observed in all mice. Fig. 2 


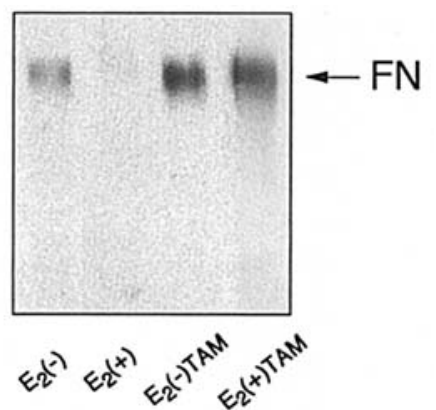

Figure 4. Effects of $17 ß$-estradiol $\left(\mathrm{E}_{2}\right)$ and tamoxifen (TAM) on cellular fibronectin (FN) expression by Western blots in MCF-7 tumors in the in vivo experiment. Sample preparation for grown tumors is described in Materials and methods. FN expression in the tumors of $\mathrm{E}_{2}(+)$ mice was lower than that of $\mathrm{E}_{2}(-)$ mice. TAM increased $\mathrm{FN}$ expression in the tumors regardless of $\mathrm{E}_{2}$ pellet.

shows the effects of $\mathrm{E}_{2}$ and TAM on tumor growth of MCF-7 tumor implanted in athymic mice. Tumor growth continued in the $\mathrm{E}_{2}(+)$ group. The tumor size was reduced significantly $(\mathrm{p}<0.01)$ in the $\mathrm{E}_{2}(-)$ group, compared with the $\mathrm{E}_{2}(+)$ group. TAM significantly inhibited MCF-7 tumor growth in the high estrogen environment $\left[\mathrm{E}_{2}(+)\right.$ vs. $\left.\mathrm{E}_{2}(+) \mathrm{TAM}, \mathrm{p}<0.01\right]$. Tumor growth was blocked and nearly ceased after treatment in the $\mathrm{E}_{2}(+) \mathrm{TAM}$ group. However, TAM did not induce further reduction of the tumor size in the low estrogen environment $\left[\mathrm{E}_{2}(-)\right.$ vs. $\left.\mathrm{E}_{2}(-) \mathrm{TAM}, \mathrm{NS}\right]$.

Levels of FN expression in MCF-7 cells in vitro. Specimens, cells (in vitro) or tumors (in vivo), were homogenized and assayed for FN by Western blots. The antibody to FN reacted with all samples at a position of the protein weight $\sim 220 \mathrm{kDa}$. Fig. 3 shows the effects of $\mathrm{E}_{2}$ and TAM on FN expression in $\mathrm{MCF}-7$ cells in the in vitro experiment. FN expression in MCF-7 cells was decreased by incubating with $10^{-9} \mathrm{M} \mathrm{E}_{2}$ and increased with $10^{-6} \mathrm{M}$ TAM. The effect of TAM increasing FN expression was inhibited by incubation with $10^{-9} \mathrm{M} \mathrm{E}_{2}$ (Fig. 3A).

FN expression is thought to be regulated by a variety of growth factors such as TGF- $\beta$, and therefore, we examined whether or not the regulatory effects of TAM on FN expression were mediated by TGF- $B$. FN expression upregulated by incubating with TAM was decreased by incubation with $1 \mu \mathrm{g} / \mathrm{ml}$ of TGF- $\beta 1$ neutralizing antibody (Fig. 3B). These results suggested that TAM increased FN expression of MCF-7 breast carcinoma cells and that these regulatory effects of TAM on FN expression were at least partly mediated by TGF- 3 .

Levels of FN expression in MCF-7 tumors in vivo. Fig. 4 shows the effects of $\mathrm{E}_{2}$ and TAM on FN expression in MCF-7 tumors in the in vivo experiment. $\mathrm{FN}$ expression in the tumors of $\mathrm{E}_{2}(+)$ mice was lower than that of $\mathrm{E}_{2}(-)$ mice. However, TAM increased $\mathrm{FN}$ expression in the tumors regardless of the $\mathrm{E}_{2}$ pellet. These results suggested that TAM increased FN expression of MCF-7 breast carcinoma cells, also in vivo, and that the regulatory effect of TAM on $\mathrm{FN}$ in vivo differed somewhat from that of in vitro.

\section{Discussion}

Several studies suggest that FN is related to tumor invasion and metastasis $(4,7,9-11,22,23)$. Takei and his co-workers reported that the stromal FN expression analyzed was a prognostic indicator of patients with breast cancer (8) and that microvessel count, which correlated with lymph node metastasis, TNM stage, recurrence, and mortality, was relatively low in stromal FN-positive tumors (24). Thus, from the point of view of invasion and metastasis, it is important to investigate the inducers on FN expression of carcinoma.

In the present study, $\mathrm{E}_{2}$ stimulated growth and inhibited cellular FN expression of estrogen-dependent MCF-7 carcinoma, both in vitro and in vivo. Although $\mathrm{E}_{2}$ is the most potent growth stimulator for ER-positive breast carcinomas; its effects on other carcinoma cells are various. In addition, its effect on FN expression of carcinoma cells remains to be clarified. For example, Landström and his colleagues (13) reported that the growth of rat prostatic adenocarcinoma (Dunning R3327) was inhibited by castration and estrogen treatment, and that FN of both plasma and cellular types increased. The effect of $\mathrm{E}_{2}$ on $\mathrm{FN}$ expression is contrary to its effect on tumor growth of certain carcinomas. Inducers that stimulate FN expression of carcinoma are likely to suppress the progression of carcinoma.

We used 60-day sustained release pellets of $E_{2}$ and TAM to treat tumor-bearing athymic mice. The $\mathrm{E}_{2}$ level was targeted to be within the range normally observed in premenopausal patients during TAM therapy (300-400 pg/ $\mathrm{ml}$ ). The TAM level we selected was $3-4 \mathrm{ng} / \mathrm{ml}$, which was slightly lower than clinical dosage.

Cellular FN expression in MCF-7 cells increased by TAM, both in vitro and in vivo. The stimulating effect of TAM on FN expression was, however, inhibited by incubation with $\mathrm{E}_{2}$ in vitro, by contrast, it was observed regardless of $\mathrm{E}_{2}$ in vivo. Thus, the in vivo regulation of FN by TAM differs from that in vitro. FN expression is regulated by a variety of growth factors and hormones in vivo; thus, the effects of TAM might be influenced by such mediators. Based on the in vivo analyses, TAM might increase FN expression either in premenopausal or postmenopausal patients.

The correlation between growth of MCF-7 cells or tumors and $\mathrm{FN}$ expression is notable. In vitro, when $\mathrm{MCF}-7$ cells were incubated with TAM $\left(10^{-6} \mathrm{M}\right)$ together with $\mathrm{E}_{2}\left(10^{-9} \mathrm{M}\right)$, cell growth approximated that of control level; however, FN expression under TAM with $\mathrm{E}_{2}$ treatment decreased below that of the control level. In vivo, to the contrary, tumor growth of the $\mathrm{E}_{2}(-) \mathrm{TAM}$ group approximated to the level of the $\mathrm{E}_{2}(-)$ group, but $\mathrm{FN}$ expression in the tumors of the $\mathrm{E}_{2}(-) \mathrm{TAM}$ group increased more than that of the $\mathrm{E}_{2}(-)$ group. From our results, it was suggested that growth of carcinoma and FN expression are not always inverse.

TGF- 3 is thought to stimulate FN expression (12). Knabbe and co-authors demonstrated that MCF-7 carcinoma cells secreted TGF- $\beta$ and that antiestrogens increased the secretion by MCF-7 cells (15). We examined whether or not the regulatory effects of TAM on FN expression were regulated by TGF- 3 . TGF- $\$ 1$ neutralizing antibody has been found to be capable of neutralizing a number of physiological effects produced by TGF- $\beta 1$. By incubation with TGF- $\beta$ neutralizing 
antibody, FN expression upregulated by TAM decreased in vitro. The results suggest that the stimulating effect of TAM on FN expression of MCF-7 breast carcinoma cells is at least partly mediated by TAM-induced TGF- $\beta$.

We conclude that TAM has a stimulating effect on FN expression in MCF-7 breast carcinoma cells both in vitro and in vivo, and that the stimulating effect of TAM on FN expression might be at least partly mediated by TAMinduced TGF- $B$. These results suggest that TAM has suppressive effects on invasion or metastasis potential, from the point of view of FN expression, as well as cell proliferation of breast cancer.

\section{References}

1. Yamada KM and Olden K: Fibronectin-adhesive glycoproteins of cell surface and blood. Nature 275: 179-184, 1978.

2. Atherton BT and Hynes RO: A difference between plasma and cellular fibronectins located with monoclonal antibodies. Cell 25: 133-141, 1981

3. Humphries MJ, Obara M, Olden K and Yamada KM: Role of fibronectin in adhesion, migration, and metastasis. Cancer Invest 7: 373-393, 1989.

4. Humphries MJ, Yasuda Y, Olden K and Yamada KM: The cell interaction sites of fibronectin in tumor metastasis. Ciba Found Symp 141: 75-93, 1988.

5. Peltonen J, Jaakkola S, Lask G, Virtanen I and Uitto J: Fibronectin gene expression by epithelial tumor cells in basal cell carcinoma: an immunohistochemical and in situ hybridization study. J Invest Dermatol 91: 289-293, 1988.

6. Suzuki K, Ono T, Umeda M and Itoh H: Secretion of celladhesion-promoting factors, fibronectin, fibronectin fragments and a $53-\mathrm{kDa}$ protein, by human rectal adenocarcinoma cells. Int J Cancer 52: 818-826, 1992.

7. Christensen L, Nielsen M, Andersen J and Clemmensen I: Stromal fibronectin staining pattern and metastasizing ability of human breast carcinoma. Cancer Res 48: 6227-6233, 1988.

8. Takei H, Iino Y, Horiguchi $\mathrm{J}$ and Yokoe T: Immunohistochemical fibronectin staining pattern and prognosis in invasive breast carcinoma. Oncology 52: 106-111, 1995.

9. Chen LB, Summerhayes I, Hsieh P and Gallimore PH: Possible role of fibronectin in malignancy. J Supramol Struct 12: 139-150, 1979.

10. Smith HS, Riggs JL and Mosesson MW: Production of fibronectin by human epithelial cells in culture. Cancer Res 39: 4138-4144, 1979.
11. Neri A, Ruoslahti E and Nicolson GL: Distribution of fibronectin on clonal cell lines of a rat mammary adenocarcinoma growing in vitro and in vivo at primary and metastatic sites. Cancer Res 41: 5082-5095, 1981.

12. Dean DC: Expression of the fibronectin gene. Am J Respir Cell Mol Biol 1: 5-10, 1989.

13. Landström M, Bergh A, Thornell L-E, Virtanen I and Damber J-E: Estrogen treatment of Dunning tumors in castrated rats: Qualitative and quantitative morphology. Prostata 20: 199-211, 1992.

14. Early Breast Cancer Trialists' Collaborative Group: Effects of chemotherapy and hormonal therapy for early breast cancer on recurrence and 15-year survival: an overview of the randomised trials. Lancet 365: 1687-1717, 2005.

15. Knabbe C, Lippman ME, Wakefield LM, Flanders KC, Kasid A, Derynck R and Dickson RB: Evidence that transforming growth factor- $\beta$ is a hormonally regulated negative growth factor in human breast cancer cells. Cell 48: 417-428, 1987.

16. Knabbe C, Kopp A, Hilgers W, Lang D, Muller V, Zugmaier G and Jonat W: Regulation and role of TGF beta production in breast cancer. Ann NY Acad Sci 784: 263-276, 1996.

17. Takei H, Lee E-S and Jordan VC: In vitro regulation of vascular endothelial growth factor by estrogens and antiestrogens in estrogen-receptor positive breast cancer. Breast Cancer 9: 39-42, 2002 .

18. Hinegardner RT: An improved fluorometric assay for DNA. Anal Biochem 39: 197-201, 1971.

19. Laemmli UK: Cleavage of structural proteins during the assembly of the head of bacteriophage T4. Nature 227: 680-685, 1970.

20. Koibuchi Y, Iino Y, Uchida T, Nagasawa M and Morishita Y: Effects of estrogen and tamoxifen on the MAP kinase cascade in experimental rat breast cancer. Int J Oncol 11: 583-589, 1997.

21. Bradford MM: A rapid and sensitive method for the quantitation of microgram quantities of protein utilizing the principle of protein-dye binding. Anal Biochem 72: 248-254, 1976.

22. Saiki I, Murata J, Makabe T, Matsumoto Y, Ohdate Y, Kawase Y, Taguchi Y, Shimojo T, Kimizuka F, Kato I and Azuma I: Inhibition of lung metastasis by synthetic and recombinant fragments of human fibronectin with functional domain. Jpn J Cancer Res 81: 1003-1011, 1990.

23. McCarthy JB, Hagen ST and Furcht LT: Human plasma fibronectin contains multiple adhesive and motility-promoting domains for metastatic melanoma cells. J Cell Biol 102: 179-188, 1986.

24. Takei H, Iino Y, Horiguchi J, Maemura M, Koibuchi Y, Nagaoka H, Yokoe T, Oyama T and Morishita Y: Angiogenesis and stromal fibronectin expression in invasive breast carcinoma. Int J Oncol 12: 517-523, 1998. 